\title{
Detection of the neuropathogenic variant of equine herpesvirus 1 associated with abortions in mares in Poland
}

\author{
Karol Stasiak, Jerzy Rola*, Gabor Ploszay, Wojciech Socha and Jan F Zmudzinski
}

\begin{abstract}
Background: The incidence of reported cases of equine herpesvirus myeloencephalopathy (EHM) caused by infection with neuropathogenic strains of equine herpesvirus 1 (EHV-1) has markedly increased over the last decade in many Western countries. The purpose of this study was to estimate the prevalence of the neuropathogenic (G2254) and non-neuropathogenic (A2254) variants of EHV-1 among isolates associated with abortions in Polish stud farms.

Results: The results of polymerase chain reaction-restriction fragment length polymorphism (PCR-RFLP) and sequencing were consistent, and showed that two out of 64 abortions (3.1\%) were induced by the neuropathogenic genotype G2254. All remaining 18 EHV-1 positive abortion cases (28.1\%) were caused by the non-neuropathogenic genotype A2254.

Conclusions: Most of the abortions in mares in Poland from 1999 to 2012 were associated with non-neuropathogenic strains of EHV-1. However, the presented data indicate that the neuropathogenic genotype of the virus is also present in Polish stud farms. Such a presence suggests that the future emergence of EHM in Poland is probable.
\end{abstract}

Keywords: EHV-1, ORF30, Neuropathogenic genotype, Abortion

\section{Background}

Equine herpesvirus 1 (EHV-1) is a double-stranded DNA virus that occurs worldwide in all breeds of horses $[1,2]$. Infections caused by EHV-1 are important as clinical outbreaks of the disease still occur, despite preventive and control measures being taken [3,4]. Exposure to EHV-1 can cause upper respiratory tract infection in foals and young horses. In pregnant mares, the virus can be transferred across the uteroplacental barrier and infect the fetus, which can lead to late-gestation abortion. EHV-1 can also migrate with infected blood leukocytes to the central nervous system and replicate in endothelial cells of arterioles in the spinal cord and brain, causing vasculitis and thrombosis [5]; this syndrome is known as equine herpesvirus myeloencephalopathy (EHM). Previous research has shown that the neuropathogenicity of EHV-1 strains is strongly associated with a single point mutation in the open reading frame

\footnotetext{
*Correspondence: jrola@piwet.pulawy.pl

Department of Virology, National Veterinary Research Institute, Al. Partyzantow 57, 24-100 Pulawy, Poland
}

(ORF) 30 of the gene encoding viral DNA polymerase [6-8]. This mutation is a single nucleotide adenine to guanine substitution at nucleotide 2,254, corresponding to an asparagine to aspartic acid substitution. Additionally, two other studies revealed that another nucleotide substitution at nucleotide 2,258 of ORF30 could possibly be associated with neuropathogenicity $[6,9]$.

Although the clinical form of EHM is less frequently observed than the other types of EHV-1 infection, it can cause serious economic losses in breeding horses and have a very negative impact on the functioning of veterinary hospitals, riding schools, and racetracks $[4,3,10,11]$. Moreover, recent data from the United States of America (US) showed that neuropathogenic strains of EHV-1 could become an important causative agent of abortions in mares even in the absence of actual clinical signs of EHM or respiratory disease [9].

In Poland, EHV-1 abortion outbreaks in mares have been reported several times since the early 1950s [12-15]. However, there are no data on the occurrence of neuropathogenic EHV-1 strains in Poland. The purpose of this study was to determine the prevalence of 
the neuropathogenic genotype of ORF30 among the strains of EHV-1 isolated from abortion cases in Poland.

\section{Methods}

Samples

We tested tissue samples (lung, liver, spleen, heart, kidney, and placenta, if delivered) from 64 aborted fetuses that were delivered to the Department of Virology of the National Veterinary Research Institute in Pulawy between 1999 and 2012. The whole fetuses or fetal organs came from horse studs located in different regions of Poland. None of the animals had been vaccinated against EHV-1, and none of the studs had a history of respiratory and neurological disease. Necropsy reports revealed that all 64 abortions occurred during the third trimester of pregnancy. A variety of macroscopic lesions were observed in most cases, including a large amount of pleural fluid, hepatic necrosis, and pulmonary oedema. No histological investigation was done. Organ samples from aborted fetuses were stored at $-70^{\circ} \mathrm{C}$ until further processing.

Two grams of each tissue sample was used for preparation of $10 \%(\mathrm{w} / \mathrm{v})$ suspension in Eagle's Minimum Essential Medium (Sigma-Aldrich), supplemented with 1\% antibiotic solution (Antibiotic Antimycotic Solution 100x, SigmaAldrich) using ULTRA-TURRAX ${ }^{\circ}$ homogenizer. Tissue homogenates were centrifuged at 1,700 $\mathrm{x}$ g for $10 \mathrm{~min}$, and then supernatants from the same fetus were pooled together and stored at $-70^{\circ} \mathrm{C}$ until testing.

\section{DNA extraction}

DNA was extracted from every pool of tissue supernatant using a phenol-chloroform-isoamyl alcohol mixture.

\section{PCR testing}

The DNA obtained from tissue homogenates was tested for the presence of EHV-1 and EHV-4 using primers for glycoprotein B previously described by Kirisawa et al. (EHV1/4 Forward: 5'-CTT GTG AGA TCT AAC CGC AC-3'[1477-1496/1468-1487], EHV-1 Reverse: 5'-GCG TTA TAG CTA TCA CGT CC-3'[1936-1917], EHV-4 Reverse: 5'-CCT GCA TAA TGA CAG CAG TG$\left.3^{\prime}[2410-2391]\right)$ [16].

\section{Virus isolation}

EHV-1 was isolated in $25-\mathrm{cm}^{2}$ tissue culture flasks containing monolayers of RK13 cells. Flasks were inoculated and checked daily for appearance of cytopathic effect (CPE). CPE-positive flasks were frozen and stored at $-70^{\circ} \mathrm{C}$.

\section{Polymerase chain reaction-restriction fragment length polymorphism (PCR-RFLP)}

PCR-RFLP neuropathogenic/non-neuropathogenic discrimination testing was performed on EHV-1-positive samples. PCR amplification of a 380-bp fragment of ORF30 was based on a modified protocol described by Allen [17]. A 25- $\mu$ l reaction mix was prepared for PCR containing $0.05 \mathrm{U} / \mu \mathrm{l}$ AccuTaq LA DNA Polymerase, $200 \mu \mathrm{M}$ of deoxynucleotide triphosphate mix, $1 \times$ PCR buffer, $400 \mathrm{nM}$ of the primer ORF30-Forward (5' - GTG GAC GGT ACC CCG GAC-3'[2005-2022]) and ORF30-Reverse (5'-GTG GGG ATT CGC GCC CTC ACC-3'[2384-2364]) and $2.5 \mu \mathrm{l}$ DNA template, suspended in RNAse-DNAse-free water. The reaction was run in a Biometra Thermocycler (Biometra, Germany) under the following conditions: initial denaturation at $94^{\circ} \mathrm{C}$ for $3 \mathrm{~min}$, followed by 35 cycles of denaturation at $94^{\circ} \mathrm{C}$ for $30 \mathrm{~s}$, annealing at $60^{\circ} \mathrm{C}$ for $1 \mathrm{~min}$, and elongation at $72^{\circ} \mathrm{C}$ for $30 \mathrm{~s}$.

PCR products were digested with SalI enzyme [recognition site: $5^{\prime}$...G $\downarrow$ TCGAC....3'] (EURx, Poland). Digestion was performed in a $50-\mu$ l reaction mixture containing $10 \mu \mathrm{l}$ of PCR product, $5 \mu \mathrm{l} 10 \mathrm{x}$ Buffer High, $0.5 \mu \mathrm{l} 100 \mathrm{x}$ BSA (EURx), and $1 \mu \mathrm{l}$ SalI enzyme, suspended in nuclease free water. Digestion was run at $37^{\circ} \mathrm{C}$ for $2 \mathrm{~h}$ in a thermocycler. Products were visualized by electrophoresis on $1.5 \%$

\section{Table 1 Polish ORF30 genotype of EHV-1 isolates by PCR-RFLP}

\begin{tabular}{|c|c|c|}
\hline Strain designation $^{\mathrm{a}}$ & Genotype at position 2254 & Region $^{\mathbf{b}}$ \\
\hline PL/1999/I & A 2254 & LU \\
\hline PL/1999/II & A 2254 & MA \\
\hline PL/2001/I & A 2254 & LU \\
\hline $\mathrm{PL} / 2002 / \mathrm{I}$ & A 2254 & MA \\
\hline $\mathrm{PL} / 2003 / \mathrm{I}$ & A 2254 & WP \\
\hline PL/2004/I & A 2254 & LU \\
\hline PL/2004/II & A 2254 & PM \\
\hline PL/2005/I & A 2254 & WM \\
\hline PL/2006/I & A 2254 & MP \\
\hline PL/2006/II & A 2254 & LU \\
\hline PL/2007/I & A 2254 & MA \\
\hline PL/2008/I & A 2254 & DS \\
\hline PL/2009/I & A 2254 & $S L$ \\
\hline PL/2009/II & G 2254 & LU \\
\hline PL/2010/I & A 2254 & MA \\
\hline PL/2010/II & G 2254 & $S L$ \\
\hline $\mathrm{PL} / 2010 / \mathrm{III}$ & A 2254 & LU \\
\hline PL/2011/I & A 2254 & MP \\
\hline PL/2012/l & A 2254 & MA \\
\hline $\mathrm{PL} / 2012 / \|$ & A 2254 & LU \\
\hline
\end{tabular}

a Based on the year of isolation.

${ }^{b}$ Voivodship SL-Silesian; MA-Masovian; WM-Warmian-Masurian.

LU-Lublin; MP-Lesser Poland; PM-Pomeranian; DS-Lower Silesian. WP-Greater Poland. The regions are described in detail at: http://en.wikipedia.org/wiki/Voivodeships_of_Poland. 
agarose gel. DNA from two EHV-1 strains was used as a positive control: Ab4 (neuropathogenic strain) and V592 (non-neuropathogenic strain).

\section{Sequencing}

All positive samples were confirmed by sequencing the 380-bp ORF30 fragment using the Sanger method at the Institute of Biochemistry and Biophysics Polish Academy of Science (Warsaw, Poland). Nucleotide sequences were assembled and aligned using Molecular Evolutionary Genetics Analysis (MEGA) version 5.0.5. The nucleotide sequences reported in this study were submitted to GenBank under the accession numbers KR080374KR080393.

\section{Results}

PCR analysis using Kirisawa's PCR primers showed that 20 pooled samples were EHV-1 positive, but no samples were EHV-4 positive. Virus isolation was successful in all PCR positive samples, with a clearly visible CPE developing within 3-5 days after inoculation of cells (Table 1).

Amplification using ORF30-specific PCR and further digestion of PCR products with SalI enzyme showed that two of the $20 \mathrm{EHV}-1$ positive isolates were the neuropathogenic variant G2254 (10\% of EHV-1 positive isolates, and $3.1 \%$ of total abortion cases), whereas 18 were the non-neuropathogenic variant $A 2254$ (90\% of EHV-1 positive isolates, and $28.1 \%$ of all abortion cases).

Comparative nucleotide sequence analysis of the 380-bp fragment gene encoding the catalytic subunit (ORF30) of the viral DNA polymerase confirmed the presence of guanine at nucleotide position 2,254 in two isolates. The other EHV-1 isolates encoded adenine at the position 2,254 and were classified as non-neuropathogenic variants. No nucleotide substitution was found at position 2,258. The consensus alignment indicated that partial ORF30 sequences were identical to the sequences of appropriate reference strains of EHV-1: Ab4 (neuropathogenic) and V592 (non-neuropathogenic) (Figure 1).

\section{Discussion}

There have been no previous reports of EHM outbreaks in Poland, and no potentially neuropathogenic variants of EHV-1 have previously been identified [18]. We have shown, for the first time, that the neuropathogenic genotype of EHV-1 circulates in the horse population in Poland. There was a clear predominance of the nonneuropathogenic (90\% of EHV-1 positive cases) over the neuropathogenic EHV-1 genotype (10\% of EHV-1 positive cases) as a causative agent of abortions in Polish stud farms. This proportion is similar to the results of recent studies in which abortion was associated with the neuropathogenic variant of EHV-1 in $0.9 \%$ of abortion cases in Japan [19], 7\% in Argentina [20], 8.9\% in Central Kentucky of the US [9], 10.6\% in Germany [21], and $25.9 \%$ in France [22].

In contrast to a few abortion outbreaks in Argentina and Germany that were associated with neurological signs in mares, there were no clinical signs indicating EHM in any case of aborted fetuses tested in this study. These results are not unusual as previous studies have proved that although the presence of the

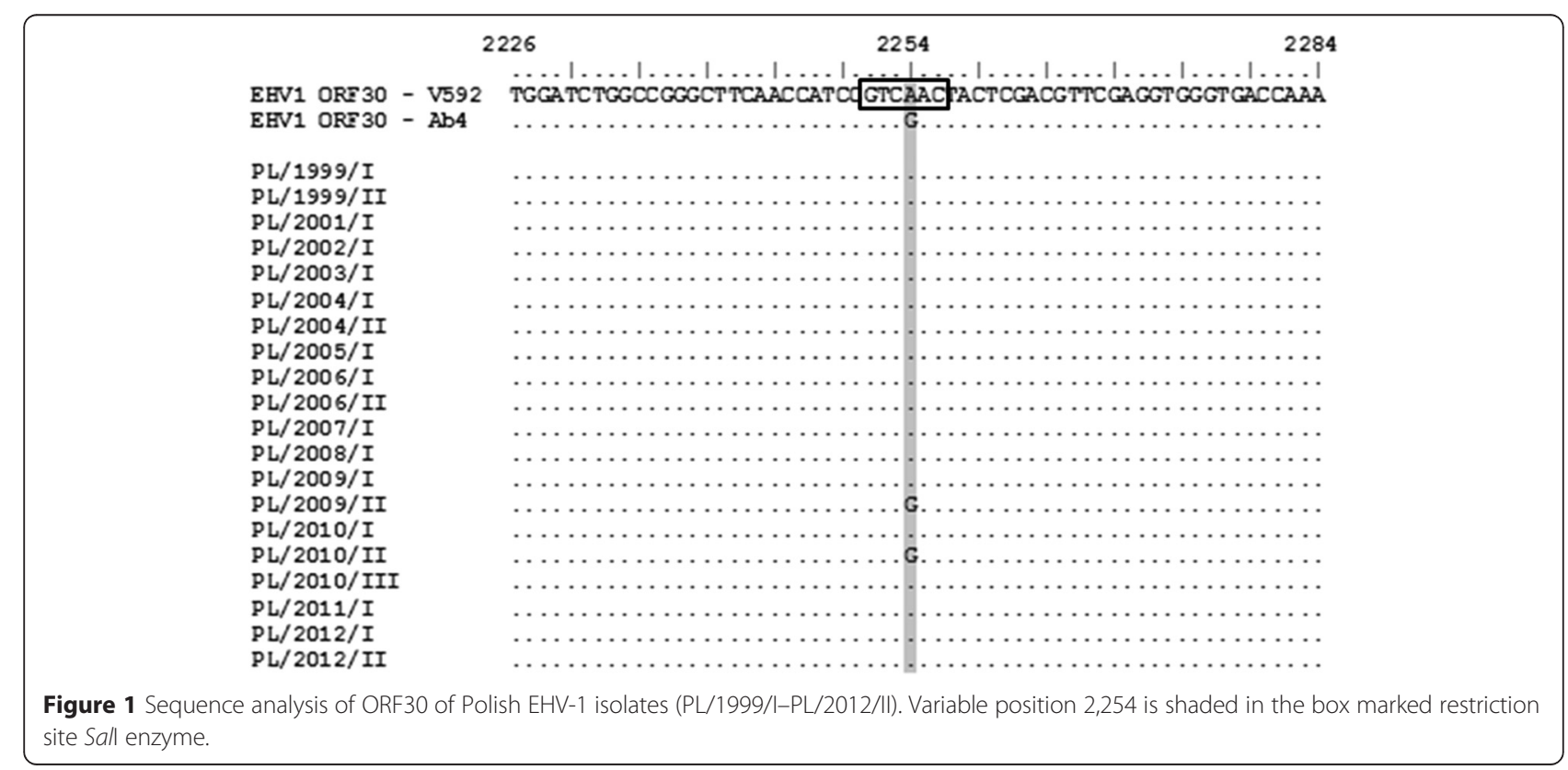


neuropathogenic strain is a factor fostering an increase in EHM cases, it is not the only factor that determines the appearance of neurological disease in infected horses $[23,24]$. For example, a German study found that only two out of seven abortion cases caused by neuropathogenic EHV-1 strains were associated with EHM signs in pregnant mares [21]. Some studies have associated EHM with the presence of another substitution (adenine to cytosine) in ORF30 at the 2,258 position [9,21]; however, this was not detected in our study.

The EHV-1 isolates possessing a nucleotide substitution from $A$ to $G$ at the 2,254 position were detected in two distant provinces of Poland, hence it is unlikely that the abortions were caused by the same strain of the virus. As this study concentrated on abortion cases, only a fraction of the total EHV-1 infections in Poland were analyzed, whereas a previous study by Pronost et al. showed that the G2254 genotype could also be associated with respiratory disease [22]. It is also possible that some of our cases were caused by mixed infection with two viral strains. Allen et al. described the occurrence of dual infections in the Thoroughbred broodmare population, with both neuropathogenic and nonneuropathogenic strains involved [25]. A similar situation took place in the case of horses infected after natural exposure at a racetrack in California [26]. Unfortunately, the diagnostic techniques used in our study were not able to detect simultaneous infection with both genotypes.

Finally, it cannot be excluded that EHM cases may have already appeared in Poland, but were either not reported or not identified properly by veterinarians. Even if this assumption is wrong, the fact that the G2254 ORF30 variant of EHV-1 is present in the horse population means that the risk of EHM outbreaks in Poland should be taken into consideration.

\section{Conclusion}

The presented data demonstrate that the neuropathogenic genotype of EHV-1 is present in Polish stud farms. Of the $20 \mathrm{EHV}-1$ abortion isolates, the vast majority belonged to the non-neuropathogenic marker A2254 (18 out of 20 isolates, which was $90 \%$ ), with only two out of the 20 isolates (10\%) identified as the neuropathogenic genotype G2254. However, the presence of neuropathogenic EHV-1 strains in Polish studs suggests that the emergence of EHM cases in Poland is probable.

\section{Availability of supporting data}

The data sets supporting the results of this article are included within the article.

\section{Competing interests}

The authors declare that they have no competing interests.

\section{Authors' contributions}

JR designed the study, isolated viral strains, and prepared the manuscript. KS, WS, and GP carried out the laboratory work, molecular genetic studies, sequence analysis, and manuscript preparation. JFZ reviewed the manuscript. All authors read and approved the final manuscript.

\section{Acknowledgments}

The authors thank Elwira Orlowska and Malgorzata Glowacka for their technical assistance.

Received: 27 November 2014 Accepted: 21 April 2015

Published online: 01 May 2015

\section{References}

1. Paillot R, Case R, Ross J, Newton R, Nugent J. Equine herpes virus-1: virus, immunity and vaccines. Open Vet Sci J. 2008;2:68-91.

2. Harless W, Pusterla N. Equine herpesvirus 1 and 4 respiratory disease in the horse. Clin Tech Equine Pract. 2006;5:197-202.

3. Friday PA, Scarratt WK, Elvinger F, Timoney PJ, Bonda A. Ataxia and paresis with equine herpesvirus type 1 infection in a herd of riding school horses. J Vet Intern Med. 2000;14:197-201.

4. Henninger RW, Reed SM, Saville WJ, Allen GP, Hass GF, Kohn CW, et al. Outbreak of neurologic disease caused by equine herpesvirus-1 at a university equestrian center. J Vet Intern Med. 2007;21:157-65.

5. Edington N, Bridges CG, Patel JR. Endothelial cell infection and thrombosis in paralysis caused by equid herpesvirus-1: equine stroke. Arch Virol. 1986;90:111-24.

6. Nugent J, Birch-Machin I, Smith KC, Mumford JA, Swann Z, Newton JR, et al. Analysis of equid herpesvirus 1 strain variation reveals a point mutation of the DNA polymerase strongly associated with neuropathogenic versus nonneuropathogenic disease outbreaks. J Virol. 2006;80:4047-60.

7. Goodman LB, Loregian A, Perkins GA, Nugent J, Buckles EL, Mercorelli B, et al. A point mutation in a herpesvirus polymerase determines neuropathogenicity. PLoS Pathog. 2007:3:1583-92.

8. Perkins GA, Goodman LB, Tsujimura K, Van de Walle GR, Kim SG, Dubovi EJ, et al. Investigation of the prevalence of neurologic equine herpes virus type 1 (EHV-1) in a 23-year retrospective analysis (1984-2007). Vet Microbiol. 2009;139:375-8.

9. Smith KL, Allen GP, Branscum AJ, Cook RF, Vickers ML, Timoney PJ, et al. The increased prevalence of neuropathogenic strains of EHV-1 in equine abortions. Vet Microbiol. 2010;141:5-11.

10. van Maanen C, Sloet Van Oldruitenborgh Oosterbaan M, Damen EA, Derksen AGP. Neurological disease associated with EHV-1 infection in a riding school: clinical and virological characteristics. Equine Vet J. 2001;33:191-6.

11. Pronost S, Legrand L, Pitel PH, Wegge B, Lissens J, Freymuth F, et al. Outbreak of equine herpesvirus myeloencephalopathy in France: a clinical and molecular investigation. Tran Emer Dis. 2012;59:256-63.

12. Bazanow B, Jackulak N, Florek M, Staronowicz Z. Equid herpesvirus- associated abortion in Poland between 1977-2010. J Equine Vet Sci. 2011;32:747-51.

13. Frymus T, Kita J, Woyciechowska S, Ganowicz M. Foetal and neonatal foal losses on equine herpesvirus type 1 (EHV-1) infected farms before and after EHV-1 vaccination was introduced. Pol Arch Weter. 1986;26:7-14.

14. Rola J, Zmudzinski J. Equine herpesvirus type 1 (EHV-1) a cause of mare's abortions in Poland. Med Weter. 1997:53:268-9.

15. Woyciechowska S. Adaptacja krajowego wirusa zakaźnego ronienia klaczy, szczep Rac-Heraldia do chomików syryjskich. Med Dosw Mikrobiol. 1960:XII 3:255-63.

16. Kirisawa R, Endo A, Iwai H, Kawakami Y. Detection and identification of herpesvirus-1 and -4 by polymerase chain reaction. Vet Microbiol. 1993;36:57-67.

17. Allen GP. Antemortem detection of latent infection with neuropathogenic strains of equine herpesvirus-1 in horses. Am J Vet Res. 2006;67:1401-5.

18. Ploszay G, Rola J, Zmudzinski JF. Neurologic form of equine herpesvirus 1 infection as a new emerging infectious disease of horses. Med Weter. 2012;68:65-128.

19. Tsujimura K, Oyama T, Katayama Y, Muranaka M, Bannai H, Nemoto M, et al. Prevalence of equine herpesvirus type 1 strains of neuropathogenic genotype in a major breeding area of Japan. J Vet Med Sci. 2011;73:1663-7 
20. Vissani MA, Becerra ML, Olguin Perglione C, Tordoya MS, Mino S,

Barrandeguy M. Neuropathogenic and non - neuropathogenic genotypes of Equid Herpesvirus type 1 in Argentina. Vet Microbiol. 2009;139:361-4.

21. Fritsche AK, Borchers K. Detection of neuropathogenic strains of Equid Herpesvirus 1 (EHV1) associated with abortions in Germany. Vet Microbiol. 2011;147:176-80

22. Pronost S, Leon A, Legrand L, Fortier C, Miszczak F, Freymuth F, et al. Neuropathogenic and non - neuropathogenic variants of equine herpesvirus 1 in France. Vet Microbiol. 2010;145:329-33.

23. Allen GP. Risk factors for development of neurologic disease after experimental exposure to equine herpesvirus- 1 in horses. Am J Vet Res. 2008;69:1595-600.

24. Pronost S, Cook RF, Fortier G, Timoney PJ, Balasuriya UBR. Relationship between equine herpesvirus-1 myeloencephalopathy and viral genotype. Equine Vet J. 2010;42:672-4.

25. Allen GP, Bolin DC, Bryant U, Carter CN, Giles RC, Harrison LR, et al. Prevalence of latent, neuropathogenic equine herpesvirus-1 in the Thoroughbred broodmare population of central Kentucky. Equine Vet J. 2008:40:105-10.

26. Pusterla N, Wilson WD, Mapes S, Finno C, Isbell D, Arthur RM, et al. Characterization of viral loads, strain and state of equine herpesvirus-1 using real- time PCR in horses following natural exposure at a racetrack in California. Vet J. 2009;179:230-9.

\section{Submit your next manuscript to BioMed Central and take full advantage of:}

- Convenient online submission

- Thorough peer review

- No space constraints or color figure charges

- Immediate publication on acceptance

- Inclusion in PubMed, CAS, Scopus and Google Scholar

- Research which is freely available for redistribution 